\title{
Towards an efficient starter culture to produce dawadawa botso: a traditional condiment produced by fermentation of Hibiscus sabdariffa seeds
}

\author{
A. D. IBRAHIM ${ }^{1 *}$, S.U. DANDARE ${ }^{2}$, I. MUKHTAR SA'ADAT ${ }^{3}$, S.A. ADAMU $^{4}$, \\ I. JUMARE FATIMA ${ }^{4}$ and Sa'adatu A. SHINKAFI ${ }^{5}$ \\ ${ }^{I}$ Department of Microbiology, Usmanu Danfodiyo University, Sokoto. Nigeria. \\ ${ }^{2}$ Department of Biochemistry, Usmanu Danfodiyo University, Sokoto. Nigeria. \\ ${ }^{3}$ Department of Microbiology and Biotechnology, Federal University Dutse, Jigawa State. \\ ${ }^{4}$ Department of Microbiology, Sokoto State University, Sokoto. Nigeria. \\ ${ }^{5}$ Department of Biological Sciences, Federal University Gusau, Nigeria. \\ * Corresponding author; E-mail: ibrahim.aliyu@udusok.edu.ng
}

\section{ACKNOWLEDGEMENTS}

The authors sincerely appreciate the funding support from Nigeria-São Tomé and Príncipe Joint Development Authority through the Nigeria-São Tomé and Príncipe postgraduate scholarship for the year 2010 ( granted to $A D I$ ).

\begin{abstract}
Dawadawa botso is a nutritious traditional condiment produced by the fermentation of the seeds of Roselle (Hibiscus sabdariffa); it often features in the food of local people in West Africa. Despite the acceptance and importance of this traditionally produced food condiment, it has received little scientific attention. This study was carried out to evaluate the effect of different combinations of fermenting bacteria on the production of dawadawa botso with a view to determining the best starter culture. Isolated fermenting organisms were used to produce dawadawa botso, and their effect on its $\mathrm{pH}$, proximate composition, mineral content and the amino acid profile was determined. The highest $\mathrm{pH}$ of 7.22 and lowest of 6.58 was recorded during the fermentation studies. Significant variations $(\mathrm{P}<0.05)$ were observed in some of the proximate and mineral compositions of dawadawa botso produced with different starter cultures. Lowest and highest values recorded for lipid was 2.17 and $15.50 \%$ respectively, and that of protein and carbohydrate were (15.12 and $27.56 \%)$ and (11.04 and 40.72\%) respectively. The order of abundance of the mineral content followed the pattern potassium $>$ sodium $>$ phosphorus $>$ magnesium $>$ calcium, showing the most to least in quantity. The major amino acids detected are glutamic acid, aspartic acid and leucine in the unfermented seeds. However, variations were observed after fermentation with the starter cultures. Dawadawa botso produced with all the organisms showed an increase in MSG-like free amino acid classes with 1F organisms showing the lowest value after fermentation. Sweet and bitter free amino acids decreased for the starter combinations used. This finding suggests that the types of fermenting organisms influence the nutritional and organoleptic properties of dawadawa botso.
\end{abstract}

(C) 2018 International Formulae Group. All rights reserved.

Keywords: Dawadawa botso, Hibiscus sabdariffa, chemical composition, amino acid. 


\section{INTRODUCTION}

Despite their prominent role as causative agents of numerous diseases, microorganisms also confer several advantages to their hosts. Some advantageous effects of microorganisms include their ability to metabolise foods easily, immune system enhancement and restoration of the gastrointestinal flora following their consumption (Mohamadou et al., 2009). Certain microbes have been demonstrated to have health benefits when consumed under some circumstances; these microbes are referred to as probiotics. Lactic acid bacteria are a few members of these groups of microbes that have been identified to possess such activity (Sanders et al., 2003).

Microorganisms have been shown to be involved in the production of traditional food condiments, one of which is dawadawa botso. Dawadawa botso is called as such in Nigeria and Niger. It is known as Bikalga in Burkina Faso, furundu in Sudan, Mbuja in Cameroon and datou in Mali (Ouoba et al., 2007; Nkafamiya et al., 2017). Dawadawa botso is a traditional nutritious condiment often used in the preparation of soup and stew in most West African countries including Nigeria. It is said to enhance meatiness in dishes and considered to be a good source of protein for the poor (Christiana and Marcel, 2008; Diawara et al., 2000). Dawadawa botso is produced by several steps with the principal one being the solid-state fermentation of the seeds of roselle (Hibiscus sabdariffa). Briefly, the selected seeds are softened by boiling in water or alkaline conditions $(\mathrm{pH} 8)$; allowed to undergo fermentation ( $48 \mathrm{~h}$ ); pounded; allowed to ferment again $(24 \mathrm{~h})$; steamed; dried; roasted and finally shaped into small balls for conservation and storage (Yagoub et al., 2004; Mohammed and Yagoub, 2007; Ouaba et al., 2007).

Several studies have implicated microorganisms in the production of food condiments (Mohammadou et al. 2007; Ibrahim et al. 2011; Koko et al., 2012). The principal microorganisms involved in the fermentation of Hibiscus. Sabdariffa seeds were found to be Bacillus species especially B. subtilis (Azokpota et al., 2007; Ouoba et al., 2007). Mohamadou et al. (2007) also reported Bacillus species as the main microorganisms together with three species of lactic acid bacteria involved in the fermentation of $H$. sabdariffa seed. Several former studies have also shown the importance of Bacillus in the fermentation of other proteinaceous seeds for the production of traditional condiments (Steinkraus, 1992; Mohamadou et al., 2010). Fermentation has been shown to produce enzymes such as cellulases which enhance the digestibility of foods (Murad and Azzaz, 2010), inhibit the growth of pathogenic bacteria (Gutiérrez et al., 2016) and enrich the nutritional status of foods by providing essential fatty acids, amino acids and micronutrients such as vitamins (Borresen et al., 2012).

Although consumers well accept dawadawa botso for its nutritional, aromatic and organoleptic properties, its fermentation is spontaneous as the microflora present on the raw material is used for initiating fermentation. This often results in differences in the taste and nutritive value of the condiment. The microbial consortium and their contribution to the properties of dawadawa botso have been studied (Yagoub et al., 2004; Mohammed and Yagoub, 2007; Mohamadou et al., 2009). However, there is no study carried out to determine the best starter culture for the production of a better palatable and nutritious dawadawa botso. It is on this ground that this research was conducted to assess the effect of microorganisms on the chemical compositions and amino acids profile of dawadawa botso using different combinations of organisms based on their proteolytic and amylolytic potentials.

\section{MATERIALS AND METHODS \\ Sample collection and processing}

Two "Mudu" of the seeds of Hibiscus sabdariffa were purchased from Zuru market, Zuru Local Government Area of Kebbi State, Nigeria. Locally prepared dawadawa botso was collected from a local producer in kwendo village of Zuru Local Government Area, Kebbi State, who is adjudged the best producer of dawadawa botso by her 
colleagues and consumers. Stalks of dried Sorghum were obtained from a harvested farm in Kwendo, Zuru, Kebbi State Nigeria and burnt to ashes. It was allowed to cool down to room temperature before packaged into a clean bag and brought to the laboratory.

\section{Source of isolates}

The fermenting organisms were isolated from locally produced dawadawa botso, purified by continuous subculture and maintained on a slant and refrigerated until required. These organisms were identified following series of biochemical tests as described by Holt et al. (1994). The isolates were identified as Bacillus Pumilus, Bacillus subtilis, Bacillus laterosporus, Bacillus polymyxa, Bacillus amyloliquefaciens, Bacillus licheniformis, Bacillus brevis, Leuconostoc mesenteriodes, Lactobacillus plantarum and Pediococcus pentasaceus, Staphylococcus species.

\section{Bacterial inoculum preparation}

The inoculum preparation was performed as described by Opara and Odibo (2009). A bacterial suspension of fresh colonies pre-inoculated into a nutrient broth was used, and the preparation of the inoculum was done by incubating bacterial cultures for $24 \mathrm{~h}$ and suspending the active young colonies in sterile distilled water to give an approximate concentration of $10^{8}$ cellsmL $^{-1}$ $\left(\mathrm{CFU} \mathrm{mL} \mathrm{m}^{-1}\right)$ adjusted with a haemocytometer.

\section{Screening for effect of fermenting organisms}

The seeds were sorted, washed with clean water two to three times, cooked for 812 hours, spread on wide glass petri-dishes (16-20 $\mathrm{cm}$ in diameter), closed and autoclaved at $121{ }^{\circ} \mathrm{C}$ for 15 minutes. After autoclaving, the seeds were plated out to ascertain the presence or absence of organism on the seeds. The ones that showed no growth upon plating out and incubation were inoculated with the isolated organisms. The count obtained was multiplied or divided to get the rough estimate of $10^{6}$ to $10^{8} \mathrm{CFU} / \mathrm{ml}$ needed to ferment a particular amount of seed, this was then inoculated onto the sterile cooked seeds and were allowed to undergo first fermentation for 2 days, then pounded using sterile local mortar and pestles, then followed by the addition of ash leachate and mixed. The paste was returned to the petri-dishes and allowed to ferment again for one day; the samples were sun dried for 1-3 days. The condiment was package in different polyethene bags according to the organisms used for the fermentation. The choice of organism's combination was influenced by their ability to hydrolyse starch or gelatin or both except Staphylococcus species because the low lipolytic activity was attributed to their presence during fermentation of African locust bean for the production of dawadawa (Ouoba et al., 2003b). The organisms were grouped as follows: $1^{\mathrm{A}}=$ all organisms except Staphylococcus species, $1^{\mathrm{B}}=$ Lactobacillus plantarum, Pediococcus pentasaceus, Bacillus subtilis, Bacillus brevis and Bacillus licheniformis, $\quad 1^{\mathrm{C}}=$ Leuconostoc mesenteriodes, Pediococcus pentasaceus, Bacillus polymyxa, Bacillus subtilis and Lactobacillus plantarum, $1^{\mathrm{D}}=$ Leuconostoc mesenteriodes, Lactobacillus plantarum and Pediococcus pentasaceus, $1^{\mathrm{E}}=$ Bacillus subtilis, Bacillus laterosporus, Bacillus polymyxa, Bacillus licheniformis and Bacillus brevis, $1^{\mathrm{F}}=$ Bacillus subtilis, Bacillus laterosporus, Bacillus licheniformis, Bacillus brevis and Lactobacillus plantarum.

\section{Determination of $\mathbf{p H}$}

The $\mathrm{pH}$ determination was performed as described previously for fermented seeds of African locust beans and $H$. sabdariffa (Ouoba et al., 2005; Parkouda et al., 2008). The $\mathrm{pH}$ of all treatments was measured directly using glass electrode $\mathrm{pH}$ meter (CLIDA instrument PHS-25C precision $\mathrm{pH} / \mathrm{mV}$ meter) in a mixture prepared with 10 $\mathrm{g}$ of sample and $30 \mathrm{ml}$ of distilled water.

\section{Proximate composition}

The analysis of all samples was performed in triplicate for the proximate composition as described (AOAC, 2006). Determination of the Ash content was conducted by incinerating two grams $(2 \mathrm{~g})$ each of the samples at $550{ }^{\circ} \mathrm{C}$ in lenton 
furnaces (England) overnight. Fibre was determined by drying two gram $(2 \mathrm{~g})$ each of all the samples overnight at $105{ }^{\circ} \mathrm{C}$ in the oven (Gallenhamp Oven BS) and incinerated at $550{ }^{\circ} \mathrm{C}$ for 90 minutes in Lenton Furnaces (England). The determination of the moisture content was performed by drying two gram (2 g) each of all sample treatments overnight at $105{ }^{\circ} \mathrm{C}$ in the oven (Gallenhamp Oven BS). The determination of the crude lipid was conducted by weighing a known weight of all the samples into extraction thimble, and the extraction of the lipid with chloroform/methanol (2:1 mixture) using soxhlet extraction apparatus (AOAC, 2006). The lipid extraction lasted for 15 hours and was drained into an empty preweighed flask, and the solvent ( $\mathrm{N}$-hexane) was allowed to dry in the oven (Gallenhamp Oven BS). The determination of protein $(\% \mathrm{~N} * 6.25)$ was by the Micro-Kjeldahl Method, and the soluble carbohydrate was obtained as a difference between crude protein, ash, crude lipid and crude fibre.

\section{Mineral content}

The mineral analyses of all samples were performed in triplicate as previously described (Walinga et al.; 1989; Black et al., 1965). The minerals analysed in this study include calcium, magnesium, potassium and sodium. The determination of potassium and sodium was performed using flame photometer (Corning 400 Essex, England), while the determination of calcium and magnesium was by ethylenediaminetetraacetic acid (EDTA) Titration Method.

\section{Determination of amino acid profile}

The determination of the profile of amino acids was performed using methods described by Spackman et al. (1958). The sample was dried to constant weight, and the sequential Multi-Sample Amino Acid Analyzer (TSM) was used for the analysis. Four samples with the highest characteristic of dawadawa botso aroma as described by the consumers were subjected to amino acid analysis. The samples were defatted by weighing a known weight of the dried sample into extraction thimble, and the lipid was extracted with chloroform/methanol (2:1 mixture) using soxhlet extraction apparatus (AOAC, 2006). The determination of nitrogen was performed using Kjedhal methods. Hydrolysis of the samples was conducted by weighing the defatted sample into glass ampule. Seven millilitres of $6 \mathrm{M} \mathrm{HCl}$ was added, and removal of oxygen was achieved by passing nitrogen into the vial to avoid some amino acids oxidation during hydrolyses. The glass vial was then sealed with Bunsen burner flame and put in an oven preset at $105{ }^{\circ} \mathrm{C}$ for 22 hours, and the content was filtered to remove the humins. The filtrate was then evaporated to dryness at $40{ }^{\circ} \mathrm{C}$ under vacuum in a rotary evaporator, and $5 \mathrm{ml}$ of acetate buffer ( $\mathrm{pH}$ 2.0) was used to dissolve the residue and stored in plastic specimen bottles, which were stored at $4{ }^{\circ} \mathrm{C}$. The hydrolysate was loaded into the TSM Analyzer by loading 5 to $10 \mu \mathrm{L}$ ( 5 for acidic/ neutral amino acid and 10 for basic amino acids). The hydrolysate was dispensed into the analyser cartridge. The TSM analyser is designed for separation and analyses of free acidic, neutral and basic amino acids of the hydrolysate.

\section{Grouping of free amino acid}

The grouping of free amino acid was performed by the taste characteristics described by Tseng et al. (2005). Amino acids were grouped as sweet (Ala+Gly+Ser+Thr), monosodium glutamate-like (MSG-like) (Asp+Glu), bitter (Arg+His+Ile+Leu+Met+Phe+Trp+Try+Val), and tasteless (Cys+Lys+Pro).

\section{Statistical analysis}

The data sets were expressed as the mean \pm standard deviation $(n=3)$, and the analysis of variance (ANOVA) was performed using One-Way ANOVA to test for the difference in means. Post-Hoc test using Duncan Multiple Range Test (DMRT) was conducted to test for the means that are significantly different from each other and presented by alphabets in superscripts (Duncan, 1955). A Paired sample T-Test was used to test for the significance between samples at $(\mathrm{P}<0.05)$ level of significance 
using the SPSS for Windows, version 15.0. (Chicago IL, USA).

\section{RESULTS}

\section{The pH of dawadawa botso is near neutral}

The effect of fermenting organisms on $\mathrm{pH}$ during the production of dawadawa botso was conducted, and the results are presented in Figure 1. The highest $\mathrm{pH}$ of 6.98 was recorded when a combination of $B$. subtilis, $B$. brevis, B. licheniformis and L. plantarum $(1 \mathrm{~F})$ was used for the fermentation of Hibiscus sabdariffa seeds to produce dawadawa botso. The lowest $\mathrm{pH}$ of 6.58 was recorded when a combination of Leuconostoc mesenteroides, Pediococcus pentasaceus, B. polymyxa, $B$. subtilis and B. lichiniformis (1C) was used for the fermentation. There was no significant difference $(\mathrm{P}>0.05)$ in $\mathrm{pH}$ between $1 \mathrm{C}$ and $1 \mathrm{D}$ organisms when each combination was used for the fermentation of the seeds of $H$. sabdariffa to produce dawadawa botso. A significant difference $(\mathrm{P}<0.05)$ in $\mathrm{pH}(6.86)$ was observed when all organisms isolated with the exception of Staphylococcus species (1A) was used for fermentation as compared to the other combinations such as $1 \mathrm{~B}$ which recorded a $\mathrm{pH}$ of 6.82 ; $1 \mathrm{E}$ with $\mathrm{pH} 6.80$; and $1 \mathrm{~F}$ having the highest $\mathrm{pH} 6.98$.

\section{The effect of fermenting organisms on the proximate composition of dawadawa botso}

The effect of fermenting organism culture on the proximate composition of dawadawa botso is shown in Table 1. The least and highest lipid values recorded are $2.17 \%$ and $15.50 \%$ which were obtained when $1 \mathrm{~A}$ and $1 \mathrm{E}$ organisms were used for fermentation respectively. The protein value recorded ranged from $15.12 \%$ to $27.56 \%$ for the different combinations of organisms, with dawadawa botso produced with $1 \mathrm{~A}$ having the least value while that produced with $1 \mathrm{E}$ organisms having the highest crude protein content. The carbohydrate content ranged from $11.04 \%$ for $1 \mathrm{D}$ to $40.72 \%$ for $1 \mathrm{~A}$ which consists of all the microorganisms.

A significant difference $(\mathrm{P}<0.05)$ in crude protein was observed in the different combination of organisms used in the fermentation trial with that containing all
Bacillus species (1E) having the highest protein content $(27.56 \%)$ and combination of Bacillus species and Lactic acid Bacteria (1A) showing the least value $(15.12 \%)$. There was no significant difference $(\mathrm{P}>0.05)$ in crude protein content between the combination trial involving $1 \mathrm{~B}, 1 \mathrm{C}$ and $1 \mathrm{D}$. There was a significant difference $(\mathrm{P}<0.05)$ in the lipid and soluble carbohydrate content of the fermented seeds of $H$. sabdariffa, with combination of all organisms having the least value of lipid $(2.17 \%)$, then Lactobacillus plantarum; Pediococcus pentasaceus, $B$. subtilis, $B$. brevis, B. licheniformis with $(2.67 \%)$ and Pediococcus pentasaceus, Leuconostoc mesenteroides, Lactobacillus plantarum having the highest lipid value of $15.50 \%$. On the other hand, combination of all organisms had the highest soluble carbohydrate value of $40.72 \%$ and Pediococcus pentasaceus, Leuconostoc mesenteroides, Lactobacillus plantarum having the least soluble carbohydrate value of $11.04 \%$ which was not significantly different $(\mathrm{P}>0.05)$ with the combination of Leuconastoc mesenteroides, Pediococcus pentasaceus, B. polymyxa, B. subtilis, L. plantarum

\section{The effect of starter cultures on the mineral content of dawadawa botso}

The effect of fermenting organisms on the mineral content of dawadawa botso was conducted and the result presented in Table 2 . The primary mineral in our study was potassium followed by sodium, then phosphorus, magnesium, and lastly calcium was the least mineral in dawadawa botso; with a combination of all organisms recording the highest value for magnesium and sodium and the least value for calcium and phosphorus. A significant difference $(\mathrm{P}<0.05)$ was observed in the phosphorus, sodium, potassium and calcium content of $H$. sabdariffa seeds fermented with the entire combination trail. There was no significant difference $(\mathrm{P}>0.05)$ in the magnesium content of all organisms.

The effect of fermenting organisms on amino acids profile of dawadawa botso

Comparison of unfermented seeds of H. sabdariffa and the effect of fermenting 
organisms on the amino acid profile of dawadawa botso was evaluated, and the result is presented in Table 3. When all the organisms were used as a starter culture, a decrease was observed in all the amino acids except isoleucine, arginine, and tyrosine. When combinations of lactic acid bacteria were used, an increase was found in all the amino acids except methionine, threonine, glycine, and cysteine. When combinations of Bacillus species were used, a decrease was evident in all the essential amino acids except lysine, isoleucine, and phenylalanine. While $1 \mathrm{~F}$ culture showed a decrease in all the essential amino acids except lysine and isoleucine. The results also showed that 1D culture recorded the highest value for the essential amino acids lysine, histidine, valine, isoleucine, leucine and phenylalanine and all the non-essential amino acids except glycine and cysteine.

\section{Grouping of free amino acids based on their taste characteristics}

The free amino acids groupings based on their taste characteristics as described by Tseng et al. (2005) are presented in Figure 2. Dawadawa botso fermented with all organisms showed an increase in MSG-like free amino acid classes with $1 \mathrm{~F}$ showing the least value after fermentation. A decrease was observed in sweet and bitter free amino acid for the different combinations used. However, for the tasteless free amino acid class, an increase was observed except for dawadawa botso fermented with all organisms.

The highest content of free amino acid classes was the bitter (BIT) class with $39.70 \%$ in the unfermented seeds and dawadawa botso produced using different fermenting organisms had $44.13 \%$ for $1 \mathrm{~A}, 42.30 \%$ for $1 \mathrm{D}, 40.25 \%$ for $1 \mathrm{E}$ and $44.56 \%$ for $1 \mathrm{~F}$ cultures, while the content of monosodium glutamate like (MSG-L) free amino acid class had $26.52 \%$ and dawadawa botso produced using different fermenting organisms had $26.69 \%$ for $1 \mathrm{~A}, 26.04 \%$ for $1 \mathrm{D}, 26.29 \%$ for $1 \mathrm{E}$ and $25.39 \%$ for $1 \mathrm{~F}$. The content of sweet (SWT) free amino acid class had $22.86 \%$ and $17.32 \%$, and the content of tasteless (TASTL) free amino acid class had $10.92 \%, 18.45 \%$, $19.79 \%, 21.84 \%$ and $18.43 \%$ in the unfermented and fermented seeds respectively.

Table 1: The effect of fermenting organisms on the proximate composition of dawadawa botso.

\begin{tabular}{|c|c|c|c|c|c|c|}
\hline $\begin{array}{l}\text { Proximate } \\
\text { Components }(\%)\end{array}$ & Moisture & Ash & Lipid & Fibre & $\begin{array}{l}\text { Crude } \\
\text { protein }\end{array}$ & Carbohydrate \\
\hline $1^{\mathrm{A}}$ & $11.00 \pm 0.50^{\mathrm{a}}$ & $23.50 \pm 0.50^{\mathrm{e}}$ & $2.17 \pm 0.29^{\mathrm{a}}$ & $7.67 \pm 0.29^{c}$ & $15.12 \pm 0.26^{\mathrm{a}}$ & $40.72 \pm 1.46^{\mathrm{e}}$ \\
\hline $1^{\mathrm{B}}$ & $11.33 \pm 0.29^{\mathrm{a}}$ & $23.17 \pm 0.29^{\mathrm{d}}$ & $2.67 \pm 0.29^{\mathrm{a}}$ & $7.33 \pm 0.29^{\mathrm{bc}}$ & $27.02 \pm 1.03^{\mathrm{cd}}$ & $27.83 \pm 1.26^{\mathrm{c}}$ \\
\hline $1^{\mathrm{C}}$ & $23.00 \pm 0.50^{\mathrm{d}}$ & $18.50 \pm 0.50^{\mathrm{a}}$ & $13.50 \pm 0.50^{\mathrm{f}}$ & $6.33 \pm 0.29^{\mathrm{a}}$ & $26.15 \pm 0.12^{\mathrm{cd}}$ & $12.52 \pm 0.21^{\mathrm{a}}$ \\
\hline $1^{\mathrm{D}}$ & $18.33 \pm 0.58^{\mathrm{c}}$ & $21.17 \pm 0.58^{\mathrm{b}}$ & $15.50 \pm 0.50^{\mathrm{e}}$ & $6.83 \pm 0.29^{\mathrm{ab}}$ & $27.13 \pm 0.19^{\mathrm{cd}}$ & $11.04 \pm 1.12^{\mathrm{a}}$ \\
\hline $1^{\mathrm{E}}$ & $13.00 \pm 0.29^{\mathrm{b}}$ & $22.67 \pm 0.29^{\mathrm{cd}}$ & $5.17 \pm 0.29^{\mathrm{d}}$ & $7.67 \pm 0.29^{c}$ & $27.56 \pm 0.05^{\mathrm{d}}$ & $23.93 \pm 2.95^{\mathrm{b}}$ \\
\hline $1^{\mathrm{F}}$ & $12.33 \pm 0.29^{\mathrm{b}}$ & $21.17 \pm 0.29^{\mathrm{b}}$ & $4.17 \pm 0.29^{\mathrm{c}}$ & $7.17 \pm 0.29^{\mathrm{bc}}$ & $22.75 \pm 1.80^{\mathrm{b}}$ & $32.41 \pm 0.44^{\mathrm{d}}$ \\
\hline
\end{tabular}

Each data point presented as mean $\pm \mathrm{SD}(\mathrm{n}=3)$

Means along the same column with different superscript are significantly different at $\mathrm{P}<0.05$

$1^{\mathrm{A}}=$ All organisms, $1^{\mathrm{B}}=$ Lactobacillus plantarum; Pediococcus pentasaceus, B. subtilis, B. brevis and B. licheniformis,

$1^{\mathrm{C}}=$ Leuconastoc mesenteroides, Pediococcus pentasaceus, B. polymyxa, B. subtilis, L. plantarum, $1^{\mathrm{D}}=$ Pediococcus. 


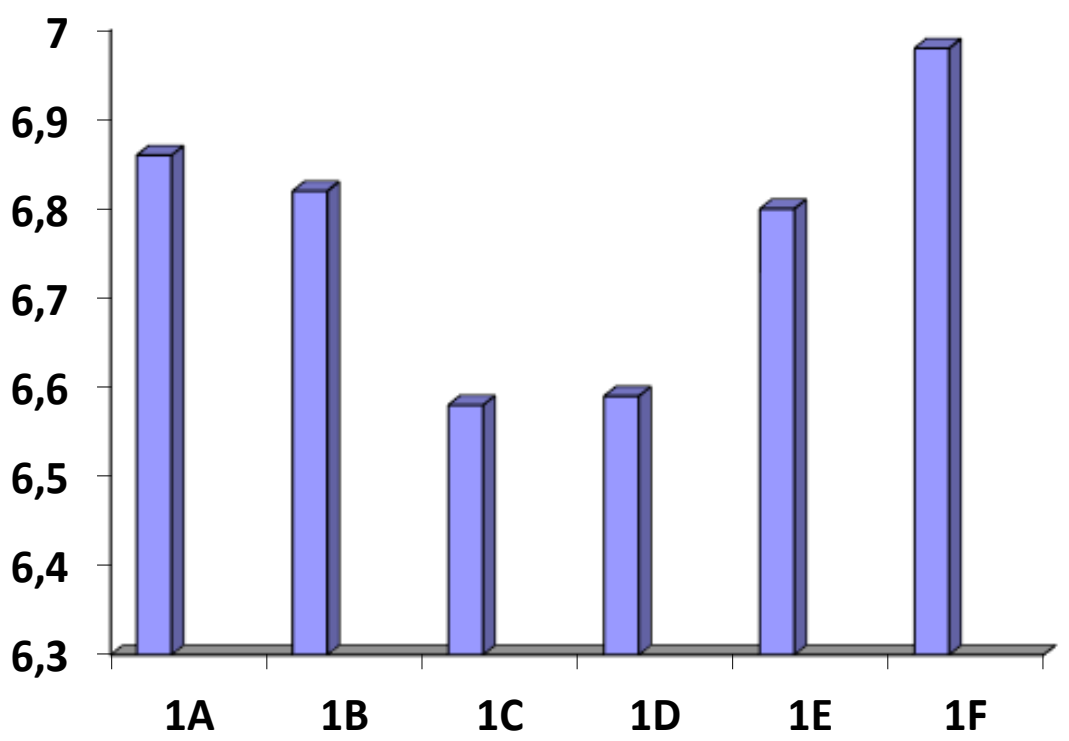

Figure 1: Effect of fermenting organisms on $\mathrm{pH}$ during the production of dawadawa botso.

A = All organisms, B = Lactobacillus plantarum; Pediococcus pentasaceus, B. subtilis, B. brevis and B. licheniformis, $\mathrm{C}=$ Leuconastoc mesenteroides, Pediococcus pentasaceus, B. polymyxa, B. subtilis, L. plantarum, D = Pediococcus pentasaceus, Leuconostoc mesenteroides and Lactobacillus plantarum, $\mathrm{E}=$ Bacillus subtilis, B. brevis, B. licheniformis and B. polymyxa, $\mathrm{F}$ $=$ B. subtilis, B. brevis, B. licheniformis and L. plantarum.

pentasaceus, Leuconostoc mesenteroides and Lactobacillus plantarum, $1^{\mathrm{E}}=$ Bacillus subtilis, B. brevis, B. licheniformis and B. polymyxa, $1^{\mathrm{F}}=$ B. subtilis, B. brevis, B. licheniformis and L. plantarum.

Table 2: The effect of fermenting organisms on the mineral content of dawadawa botso.

\begin{tabular}{cccccc}
\hline $\begin{array}{c}\text { Mineral Content } \\
(\mathbf{m g} / \mathbf{k g})\end{array}$ & Magnesium & Phosphorus & Sodium & Potassium & Calcium \\
\hline $1^{\mathrm{A}}$ & $0.95 \pm 0.05^{\mathrm{b}}$ & $2.45 \pm 0.01^{\mathrm{a}}$ & $118.33 \pm 3.82^{\mathrm{b}}$ & $16333.33 \pm 288.68^{\mathrm{d}}$ & $0.17 \pm 0.03^{\mathrm{a}}$ \\
$1^{\mathrm{B}}$ & $0.75 \pm 0.05^{\mathrm{a}}$ & $2.61 \pm 0.01^{\mathrm{ef}}$ & $113.33 \pm 5.20^{\mathrm{ab}}$ & $13083.33 \pm 381.88^{\mathrm{a}}$ & $0.27 \pm 0.03^{\mathrm{c}}$ \\
$1^{\mathrm{C}}$ & $0.80 \pm 0.10^{\mathrm{a}}$ & $2.57 \pm 0.02^{\mathrm{d}}$ & $110.00 \pm 5.00^{\mathrm{a}}$ & $14416.67 \pm 381.88^{\mathrm{c}}$ & $0.20 \pm 0.05^{\mathrm{ab}}$ \\
$1^{\mathrm{D}}$ & $0.78 \pm 0.03^{\mathrm{a}}$ & $2.60 \pm 0.02^{\mathrm{e}}$ & $132.50 \pm 2.50^{\mathrm{cd}}$ & $16083.3 \pm 381.88^{\mathrm{d}}$ & $0.27 \pm 0.03^{\mathrm{c}}$ \\
$1^{\mathrm{E}}$ & $0.83 \pm 0.03^{\mathrm{a}}$ & $2.49 \pm 0.02^{\mathrm{b}}$ & $137.50 \pm 2.50^{\mathrm{d}}$ & $13833.33 \pm 381.88^{\mathrm{bc}}$ & $0.18 \pm 0.03^{\mathrm{ab}}$ \\
$1^{\mathrm{F}}$ & $0.82 \pm 0.03^{\mathrm{a}}$ & $2.63 \pm 0.02^{\mathrm{f}}$ & $118.33 \pm 1.44^{\mathrm{b}}$ & $13416.67 \pm 288.68^{\mathrm{ab}}$ & $0.22 \pm 0.03^{\mathrm{abc}}$ \\
\hline
\end{tabular}

Each data point presented as Mean \pm SD $(n=3)$

Means along the same column with different superscript are significantly different at $\mathrm{P}<0.05$

$1^{\mathrm{A}}=$ All organisms, $1^{\mathrm{B}}=$ Lactobacillus plantarum; Pediococcus pentasaceus, B. subtilis, $\quad$ B. brevis and B. licheniformis, $1^{\mathrm{C}}$

$=$ Leuconastoc mesenteroides, Pediococcus pentasaceus, B. polymyxa, B. subtilis, L. plantarum, $1^{\mathrm{D}}=$ Pediococcus pentasaceus, Leuconostoc mesenteroides and Lactobacillus plantarum, $1^{\mathrm{E}}=$ Bacillus subtilis, B. brevis, B. licheniformis and B. polymyxa, $1^{\mathrm{F}}=$ B. subtilis, B. brevis, B. licheniformis and L. plantarum. 
Table 3: Comparison of unfermented seeds of $H$. sabdariffa and the effect of fermenting organisms on the amino acid profile of dawadawa botso.

\begin{tabular}{|c|c|c|c|c|c|}
\hline Amino acids & $\begin{array}{l}\text { Unfermented } \\
\text { Seeds }\end{array}$ & $\mathbf{1}^{\mathrm{A}}$ & $1^{\mathrm{D}}$ & $\mathbf{1}^{\mathrm{E}}$ & $\mathbf{1}^{\mathrm{F}}$ \\
\hline $\begin{array}{l}\text { Essential amino } \\
\text { acids }\end{array}$ & & & $\mathrm{g} / 10$ & Og protein & \\
\hline Lysine & 2.79 & $2.26(-0.53)$ & $4.35(1.56)$ & $4.13(1.34)$ & $3.97(1.18)$ \\
\hline Histidine & 2.26 & $1.50(-0.76)$ & $2.88(0.62)$ & $2.10(-0.16)$ & $1.69(-0.57)$ \\
\hline Threonine & 3.39 & $1.39(-2.00)$ & $1.72(-1.67)$ & $3.21(-0.18)$ & $1.55(-1.84)$ \\
\hline Valine & 3.95 & $3.78(-0.17)$ & $4.07(0.12)$ & $3.31(-0.64)$ & $3.02(-0.93)$ \\
\hline Methionine & 1.02 & $0.63(-0.39)$ & $0.83(-0.19)$ & $0.73(-0.29)$ & $0.68(-0.34)$ \\
\hline Isoleucine & 3.39 & $3.83(0.44)$ & $4.52(1.13)$ & $4.05(0.66)$ & $5.02(1.63)$ \\
\hline Leucine & 5.38 & $4.38(-1.00)$ & $5.71(0.33)$ & $5.05(-0.33)$ & $5.33(-0.05)$ \\
\hline Phenylalanine & 4.57 & $3.55(-1.02)$ & $5.24(0.67)$ & $4.73(0.16)$ & $3.89(-0.68)$ \\
\hline \multicolumn{6}{|l|}{$\begin{array}{l}\text { Non-essential } \\
\text { amino acids }\end{array}$} \\
\hline Arginine & 4.94 & $5.45(0.51)$ & $6.64(1.70)$ & $5.53(0.59)$ & $6.81(1.87)$ \\
\hline Aspartic acid & 8.35 & $6.12(-2.23)$ & $8.98(0.63)$ & $7.10(-1.25)$ & $6.92(-1.43)$ \\
\hline Serine & 2.64 & $1.67(-0.97)$ & $3.35(0.71)$ & $2.91(0.27)$ & $2.05(-0.59)$ \\
\hline Glutamic acid & 9.77 & $9.03(-0.74)$ & $10.61(0.84)$ & $11.03(1.26)$ & $9.03(-0.74)$ \\
\hline Proline & 2.97 & $3.18(0.21)$ & $3.40(0.43)$ & $2.97(0.00)$ & $2.55(-0.42)$ \\
\hline Glycine & 4.96 & $3.55(-1.41)$ & $4.57(-0.39)$ & $4.04(-0.92)$ & $3.89(-1.07)$ \\
\hline Alanine & 4.63 & $3.86(-0.77)$ & $5.25(0.62)$ & $4.90(0.27)$ & $4.09(-0.54)$ \\
\hline Cystine & 1.70 & $0.65(-1.05)$ & $1.18(-0.52)$ & $0.91(0.79)$ & $0.78(0.92)$ \\
\hline Tyrosine & 1.61 & $1.93(0.32)$ & $1.93(0.32)$ & $2.25(0.64)$ & $1.61(0.00)$ \\
\hline
\end{tabular}




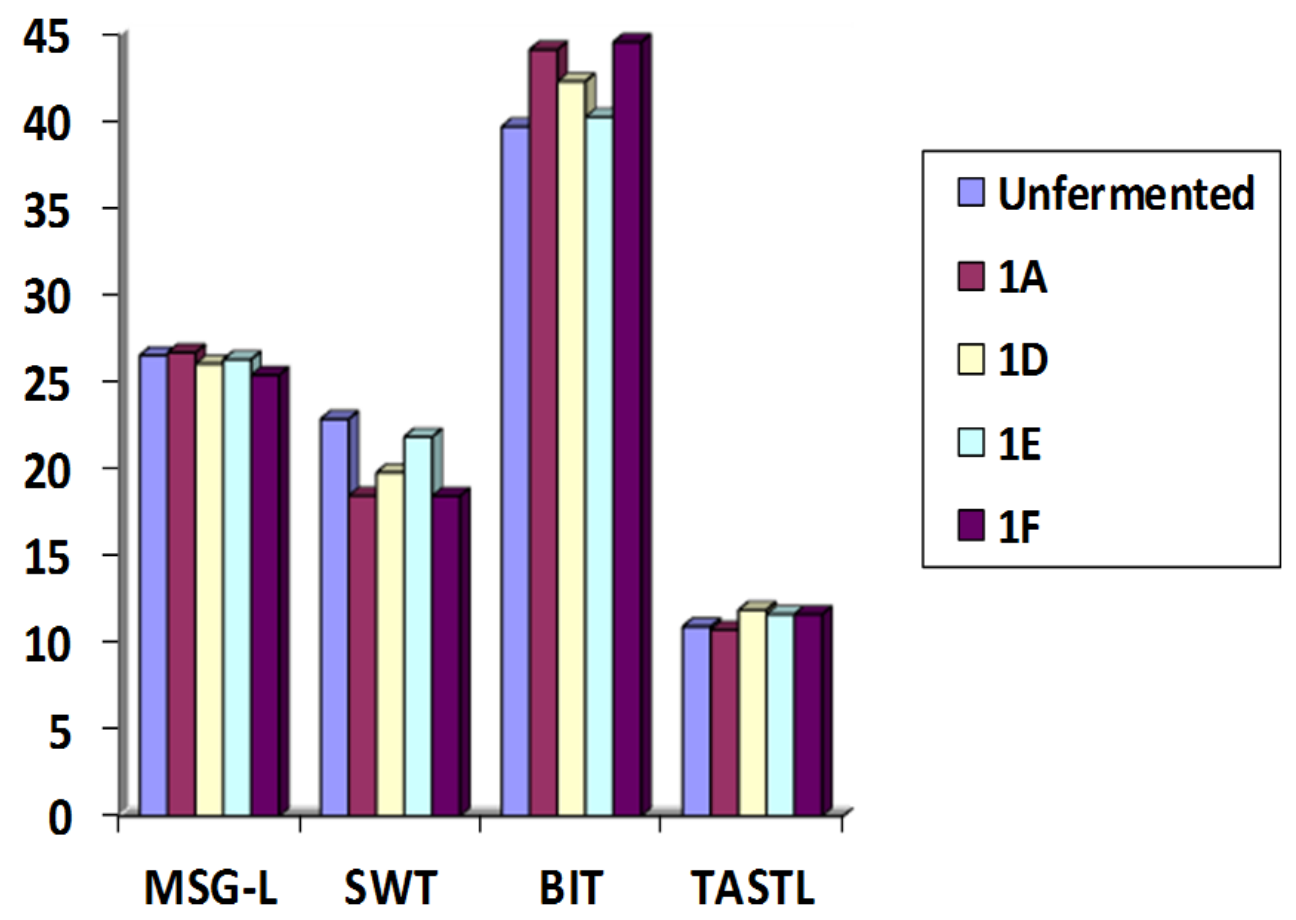

Figure 2: Free amino acid classes (\%) imparted the different taste in unfermented seeds and seeds of $H$. sabdariffa fermented with various organisms.

$1^{\mathrm{A}}=$ All organisms, $1^{\mathrm{D}}=$ Pediococcus pentasaceus, Leuconostoc mesenteroides and Lactobacillus plantarum, $1^{\mathrm{E}}=$ Bacillus subtilis, B. brevis, B. licheniformis and B. polymyxa, $1^{\mathrm{F}}=B$. subtilis, B. brevis, B. licheniformis and L. plantarum.

\section{DISCUSSION}

The data obtained from this study describes how the combination of different microflora used as starter cultures for the fermentation of $H$. sabdariffa seeds to produce dawadawa botso can influence some process parameters of the condiment such as $\mathrm{pH}$ and also quality parameters such as chemical, mineral and amino acids composition.

The $\mathrm{pH}$ and harvesting time are the critical factors among all process parameters that strongly influence the physiological state of bacteria after fermentation (Rault et al., 2009). During the production of dawadawa botso, the $\mathrm{pH}$ of the different combinations of starter cultures obtained ranged from $6.58-$ 6.98; the lower $\mathrm{pH}$ was detected in cultures dominated by lactic acid bacteria while the higher $\mathrm{pH}$ was determined in the Bacillus spp dominated starter culture.Lactic acid bacteria are better acid producers than Bacillus species (Hammes and Tichaczek, 1994; Parkouda et al., 2009) and this could be responsible for the low $\mathrm{pH}$ recorded when lactic acid bacteria were used alone or with two Bacillus species as compared to when all Bacillus species were used. Lactic acid bacteria posses the ability to initiate swift acidification of the raw production material, and this is crucial to the enhancement of texture, flavour and safety of the product (Grattepanche et al., 2008). Studies on homologous condiments such as Mbuja from Cameroon and Furundu a meat substitute from Sudan both of which were prepared with their natural microflora showed a slightly acidic $\mathrm{pH}$ than our dawadawa botso. Mbuja showed $\mathrm{pH}$ ranging between 4.73 6.53 (Mohammadou et al., 2009) while Furundu recorded $\mathrm{pH}$ ranging between 5.64 and 5.88 (Yagoub et al., 2004); the lowest pH 
in both studies was obtained after nine (9) days of fermentation.

In the proximate composition, a reciprocal relationship was observed between the carbohydrate and lipid content of dawadawa botso produced by each starter culture. The product with the highest carbohydrate content produced by $1 \mathrm{~A}$ culture has the lowest lipids and dawadawa botso produced with 1D (lactic flora dominant) starter culture which has the highest lipid content has the lowest carbohydrates. This result is mainly due to a selective utilisation of carbohydrate or lipid by the microflora during the fermentation (Ikenebomeh et al., 1986; Ibrahim and Antai, 1986). The importance of oligosaccharide metabolism to the ecological fitness of lactobacilli is well documented (Bron et al., 2004; Gänzle et al., 2007; Walter, 2008; Tannock et al., 2012); carbohydrates are preferentially utilized as its source of energy which explains why low carbohydrate content is found in lactic flora dominant starter culture (1D). 1C starter culture showed the highest moisture content. High moisture content signifies the water holding capacity of the product and thus the long life of the fermenting microorganisms due to water activity (Ajayi et al., 2015).

In all the different starter cultures tested, a similar trend in the bioavailability of the mineral content was evident. The trend followed potassium $>$ sodium $>$ phosphorus $>$ magnesium $>$ calcium. The low proportion of magnesium and calcium in all cases may be due to their presence as insoluble complexes with antinutrients; this makes them biounavailable (Mohite et al., 2013). Mineral elements are part of the nutritional factors that influence microbial growth; For instance, phosphorus is required by microbial cells for incorporation into nucleic acids, membrane lipid, and ATP. Potassium, magnesium, and calcium are needed by microbial cells for the functioning of certain enzymes (Nester et al., 2004).
In the amino acids profile (Table 3) interestingly, the lactic flora (1D) starter culture produced dawadawa botso with the highest essential and non-essential amino acids. While other starter cultures which contain mainly Bacillus spp. And combinations of both Bacillus and lactic acid bacteria decreased the number of amino acids in comparison with the unfermented seeds of H. sabdariffa. This result also reflects the utilisation/assimilation of amino acids by different microorganisms. Some strains of lactic acid bacteria have been shown to possess the ability to hydrolyse proteins found in their medium to liberate the amino acids (Lee et al., 2014). The results of amino acid profile also suggest that this condiment was enriched with branched-chain amino acids (BCAAs) namely isoleucine, leucine, and valine. The BCAAs are known to achieve positive nitrogen balance in liver disease patients and also serve as key building blocks in protein synthesis, regulation of glucose homeostasis and cell growth (Tajiri and Shimizu, 2013; Tamanna and Mahmood, 2014; Rohini et al., 2018).

In amino acids groupings based on taste, the bitter tasting amino acids were predominant followed by MSG-L, salty and finally the tasteless amino acids in dawadawa botso. This finding reflects the overall characteristic flavour of dawadawa botso which is definitively determined by the balance and interaction between different flavour components (Yanfang and Wenyi, 2009). The taste of saltiness may directly be related to the ash leachate that was added during the production process. More intensive MSG -like taste was possible due to the higher aspartic acid and glutamic acid content (Tseng et al., 2005). The unpleasant bitterness change derived from bitter free amino acids might have been diminished or masked by saltiness, MSG -like the taste, sourness and sweetness (Kim and Lee, 2003). The decrease in the content of MSG -like and sweet free amino 
acid class could also be explained by the fact that the fermenting organisms might have further biotransformed eventually to yield volatile aromatic compounds (Tavaria et al., 2002).

\section{Conclusion}

In conclusion, this study revealed that dawadawa botso fermented with Pediococcus pentasaceus, Leuconostoc mesenteroides and Lactobacillus plantarum was the best by that fermented with all Bacillus sp. Therefore, these organisms can be exploited as culture starters for the production of dawadawa botso as in the case of other fermented products. This result may also support the traditional belief that 'dawadawan botso' cures many illnesses and also delays ageing.

\section{COMPETING INTERESTS}

The authors declare that they have no competing interests.

\section{REFERENCES}

Ajayi OA, Akinrinde IM, Akinwunmi OO. 2015. Towards the development of shelfstable 'iru' (Parkia biglobosa) condiment bouillon cubes using corn, cassava and potato starch extracts as binders. Nigerian Food Journal, 33(1): 67-72.

doi.org/10.1016/j.nifoj.2015.04.006

AOAC. 2006. Official Methods of Analysis. (18th edn). Association of Official Analytical Chemists: Washington, DC.

Azokpota, P, Moller, PL, Houghouigan, JD, Jakobson, M. 2007. Biodiversity of Bacillus isolated from afitin, iru and sonru at different fermentation time. Int. J. Biol. Chem. Sci., 1(3): 211-222. http://dx.doi.org/10.4314/ijbcs.v1i3.3971 6
Black CA, Evans DD, White JL, Eneminger LE, Clark FE. 1965. Methods of Soil Analysis. Part 2. American Society of Agronomy, University of WisconsinMadison, USA. Pp. 999-1009.

Borresen EC, Henderson AJ, Kumar A, Weir TL, Ryan EP. 2012. Fermented foods: Patented approaches and formulations for nutritional supplementation and health promotion. Recent Patents on Food, Nutrition and Agriculture, 4(2): 134-140.

Bron PA, Grangette C, Mercenier A, De Vos WM, Kleerebezem M. 2004. Identification of Lactobacillus plantarum genes that are induced in the gastrointestinal tract of mice. Journal of Bacteriology, 186(17): 5721-5729. doi:10.1128/JB.186.17.5721-5729.2004

Christiana NE, Marcel JI. 2008. Processing effects of the nutritional and antinutritional content of African locust bean (Parkia biglobosa Benth) seed. Pak. J. Nutr., 7: 214-217.

Diawara B, Sawadogo L, Amoa-Awua WF, Jakobsen M. 2000. Capacity building for research and development in quality assurance and fermenta- tion technology for African fermented foods. HACCP System for Traditional African Fermented Foods: Soumbala. WAITRO.

Duncan DB. 1955. Multiple range and Multiple F-test. Biometrics, 11: 1-42.

Gänzle MG, Vermeulen N, Vogel RF. 2007. Carbohydrate, peptide and lipid metabolism of lactic acid bacteria in sourdough. Food Microbiology, 24(2): 128-138. doi.org/10.1016/j.fm.2006.07.006

Grattepanche F, Miescher-Schwenninger S, Meile L, Lacroix C. 2008. Recent developments in cheese cultures with protective and probiotic functionalities. 
Dairy Science and Technology, 88(4-5): 421-444. doi: 10.1051/dst: 2008013

Gutiérrez S, Martínez-Blanco H, RodríguezAparicio LB, Ferrero MA. 2016. Effect of fermented broth from lactic acid bacteria on pathogenic bacteria proliferation. Journal of Dairy Science, 99(4): 2654-2665. DOI: https://doi.org/10.3168/jds.2015-10439

Hammes WP, Tichaczek PS. 1994. The Potential of Lactic -Acid Bacteria for the production of Safe and Wholesome Food, Zeitschrift fur Lebenmitteltechnol, Germany.

Holt JG, Krieg NR, Sneath PHA, Staley JT, Williams ST. 1994. Bergy's Manual of Determinative Bacteriology ( $9^{\text {th }}$ Edn). Williams and Wilkins; 478-529.

Ibrahim MH, Antai SP. 1986. Chemist Changes during the fermentation of African locust bean (Parkia filicoidea Welw) Seeds for Production of Daddawa. Plant Foods Hum. Nutr., 36: 179-184.

Ibrahim AD, Sani A, Shinkafi SA. 2011. Production, microbial and physico chemical evaluation of dawadawan botso (A condiment) produced by the fermentation of Hibiscus sabdariffa seeds. Int. J. Biol. Chem. Sci., 5(6): 2481-2490.

Ikenebomeh MJ, Kok R, Ingram JM. 1986. Processing and fermentation of the African locust bean (Parkia filicoidea Welw) to produce dawadawa. J. Sci. Food Agric., 37: 273-282.

Kim SH, Lee KA. 2003. Evaluation of taste compounds in water soluble extract of a doenjang (soybean paste). Food Chem., 83: 339-342. dx.doi.org/10.1016/S03088146(03)00092-X.

Koko CA, Konan A, Tetchi F, Assidjo E, Amani G. 2012. Quality of fermented cassava flour processed into placali. Int J. Biol. Chem. Sci., 6(1): 415-420. DOI: http://dx.doi.org/10.4314/ijbcs.v6i1.36

Lee K, Kim HJ, Park SK. 2014. Amino acids analysis during lactic acid fermentation by single strain cultures of lactobacilli and mixed culture starter made from them. Africa Journal of Biotechnology, 13(28): 2867-2873. DOI: 10.5897/AJB2013.134

Mohamadou BA, Mbofung CM, Thouvenot D. 2010. Charcterization of some atypical lactic acid bacteria associated with the fermentation of Hibiscus sabdariffa seeds. African Journal of Microbiology Research, 4(24): 26552660.

Mohamadou BA, Mbofung CMF, Thouvenot D. 2009. Microbiological and organoleptic profiles of Mbuja: A traditional condiment produced by fermentation of Hibiscus sabdariffa seeds in Cameron. J. Food Technol., 7(3): 84-91.

Mohamadou BA, Mbofung CMF, Thouvenot D. 2007. Functional Potentials of a product from Traditional Biotechnology: Antioxidant and Probiotic Potential of Mbuja produced by fermentation of Hibiscus sabdariffa seeds in Cameron. $J$. Food Technol., 5(2): 164-168.

Mohammed AM, Yagoub AE. 2007. Furundu, from fermented/sprouted roselle (Hibiscus sabdariffa L.) seed: Investigation on chemical composition, antinutritional factors, $\mathrm{HCl}$-extractability of minerals, amino acids composition, in vitro protein digestibility and microbial growth. Research Journal of Agriculture and Biological Sciences, 3(6): 876-885.

Mohite BV, Chaudhari GA, Ingale HS, Mahajan VN. 2013. Effect of fermentation and processing on in vitro mineral estimation of selected fermented 
foods. International Food Research Journal, 20(3): 1373-1377.

Murad HA, Azzaz HH. 2010. Cellulase and dairy animal feeding. Biotechnology, 9(3): 238-256. DOI: 10.3923/biotech.2010.238.256.

Nkafamiya II, Atiku J, Akinterinwa A, Fari A. 2017. Effect of storage conditions on the degradation of roselle (Hibiscus sabdariffa) seeds oil. Int. J. Biol. Chem. Sci., 11(3): 1350 - 1360. DOI : https://dx.doi.org/10.4314/ijbcs.v11i3.34

Opara EU, Odibo FJC 2009. Studies and Characterization of Bacterial Spot Pathogen of Tomato Xanthomonas campestris PV Vesicatoria. J. Molecular Genetics, 1(2): 35-43.

Ouoba LII, Diawara B, Annan NT, Poll L, Jakobsen. M. 2005. Volatile compounds of Soumbala, A fermented African locust bean (Parkia biglobosa) Food condiments. J. Appl. Microbiol., 99: 1413-1421.

Ouoba LII, Parkouda C, Diawara B, Scotti C, Varnam AH. 2007. Identification of Bacillus spp. from Bikalga, fermented seeds of Hibiscus sabdariffa: Phenotypic and genotypic characterization. J. Appl. Microbiol., 104: 122-131.

Ouoba LII, Rechinger KB, Diawara B, Traore AS, Jakobsen M. 2003b. Degradation of African locust bean oil by Bacillus subtilis and Bacillus pumilus isolated from soumba, a fermented African locust bean condiment. J. Appl. Microbiol. 95: 868-873.

Parkouda C, Diawara B, Ouoba LII. 2008. Technology and physicochemical characteristics of Bikalga, alkaline fermented seeds of Hibiscus sabdariffa. African J. Biotechnol., 7(7): 916-922.

Parkouda C, Nielsen DS, Azokpota P, Ouoba LII, Amoa-Awua WK, Thorsen L,
Hounhouigan JD, Jensen JS, TanoDebrah K, Diawara B, Jakobsen M. 2009. The microbiology of alkalinefermentation of indigenous seeds used as food condiments in Africa and Asia. Crit. Rev. Microbiol., 35(2): 139-56.

Rault A, Bouix M, Béal C. 2009. Fermentation $\mathrm{pH}$ influences the physiological-state dynamics of Lactobacillus bulgaricus CFL1 during pH-controlled culture. Applied and Environmental Microbiology, 75(13): 4374-4381. DOI:10.1128/AEM.0272508

Rohini A, Agrawal N, Kumar H, Kumar V. 2018. Emerging role of branched chain amino acids in metabolic disorders: A mechanistic review. PharmaNutrition, 6(2) : $\quad 47-54 . \quad$ DOI : doi.org/10.1016/j.phanu.2018.01.003

Sanders ME, Morelli L, Tompkins TA 2003. Spore formers as Human Probiotics. Bacillus, SporoLactobacillus Brevibacillus. Comprehensive Reviews Food Science Food Safety, 12: 101-110.

Spackman DH, Stein EH, Moore S. 1958. Automatic Recording Apparatus for Use in the Chromatography of amino acids. Analytical Chem., 30: 1191.

Steinkraus KH. 1992. Lactic acid fermentations in applications of biotechnology to traditional fermented foods, report of an Ad Hoc panel of the board on science and technology for the international development, National Academy Press, Washington DC, USA.

Tajiri K, Shimizu Y. 2013. Branched-chain amino acids in liver diseases. World Journal of Gastroenterology, 19(43): 7620-7629.

DOI: 10.3748/wjg.v19.i43.7620

Tamanna N, Mahmood N. 2014. Emerging roles of branched-chain amino acid 
supplementation in human diseases. International Scholarly Research Notices, Article ID 235619, 8 pages. dx.doi.org/10.1155/2014/235619

Tannock GW, Wilson CM, Loach D, Cook GM, Eason J, O'toole PW, Holtrop G, Lawley B. 2012. Resource partitioning in relation to cohabitation of Lactobacillus species in the mouse forestomach. ISME Journal, 6(5): 927938. DOI: 10.1038/ismej.2011.161

Tavaria FK, Dahl S, Carballo FJ, Malcata FX. 2002. Amino acid catabolism and generation of volatiles by lactic acid bacteria. Journal of dairy science, 85(10): 2462-2470. DOI: doi.org/10.3168/jds.S00220302(02)74328-2

Tseng Y, Lee Y, Li R, Mau J. 2005. Nonvolatile flavour components of Ganoderma tsugae. Food Chemistry, 90(3): 409-415. DOI: doi.org/10.1016/j.foodchem.2004.03.054

Walinga T, Vanvank W, Houba VTG, Vander-Lee JJ. 1989. Plant Analysis Procedures. Part 7. Department of Soil
Science and Plant Nutrition, Wageningen. Agricultural University Wageningen. Pp. 197-200.

Walter J, Schwab C, Loach DM, Gänzle MG, Tannock GW. 2008. Glucosyltransferase A (GtfA) and inulosucrase (Inu) of Lactobacillus reuteri TMW1.106 contribute to cell aggregation, in vitro biofilm formation, and colonization of the mouse gastrointestinal tract. Microbiology, 154(1): 72-80. DOI: doi:10.1099/mic.0.2007/010637-0

Yagoub AE, Mohammed BE, Ahmed AHR, El Tinay AH. 2004. Study on furundu, a traditional Sudanese fermented roselle (Hibiscus sabdariffa L.) seed: Effect on in vitro protein digestibility, chemical composition, and functional properties of total proteins. Journal of Agricultural and Food Chemistry, 52(20): 6143-6150. DOI: 10.1021/jf0496548

Yanfang Z, Wenyi T. 2009. Flavor and taste compounds analysis in Chinese solid fermented soy sauce. African Journal of Biotechnology, 8(4): 673-681. 